\section{Analysis of Fresh Mushroom Compost}

\author{
Michael A. Fidanza ${ }^{1,3}$, David L. Sanford ${ }^{1}$, David M. Beyer ${ }^{2}$, \\ and David J. Aurentz ${ }^{1}$
}

ADDITIONAL INDEX WORDs. carbon, nitrogen, organic matter, phosphorus, potassium, soluble salts

SUMMARY. Fresh mushroom compost is a byproduct of the edible mushroom (Agaricus bisporus) industry and represents the composted growing substrate that remains after a crop has been harvested to completion. Thirty samples were obtained from commercial mushroom farms in southeastern Pennsylvania and sent to a laboratory for analysis to determine plant nutrient content, bulk density, and particle size distribution of fresh mushroom compost. Fresh mushroom compost had an average $\mathrm{pH}$ of 6.6, with an average carbon:nitrogen ratio of 13:1. Organic matter content averaged $25.86 \%$ (wet weight), $146.73 \mathrm{lb} /$ yard $^{3}$ (wet volume) or $60.97 \%$ (dry weight). For the primary macronutrients, average total nitrogen content averaged $1.12 \%$ (wet weight), $6.40 \mathrm{lb} /$ yard $^{3}$ (wet volume) or $2.65 \%$ (dry weight), phosphorus measured $0.29 \%$ (wet weight), $1.67 \mathrm{lb} /$ yard3 (wet volume) or $0.69 \%$ (dry weight), and potassium was $1.04 \%$ (wet weight), $5.89 \mathrm{lb} / \mathrm{yard}^{3}$ (wet volume) or $2.44 \%$ (dry weight). Average soluble salt content was $13.30 \mathrm{mmho} / \mathrm{cm}$ (wet weight basis). However, on a per acre basis, the calculated sodium absorption ratio of 0.38 was considered very low. The average bulk density of fresh mushroom compost was $574.73 \mathrm{lb} /$ yard $^{3}$ (wet volume basis), and $91 \%$ of the material measured $\leq 3 / 8$ inch in diameter as determined on a wet weight basis. Overall, fresh mushroom compost is suitable as a natural organic fertilizer and soil amendment for agriculture and horticulture.

$\mathrm{P}$ roduction of the edible mushroom in the United States totaled 802 million pounds during the 2007-08 growing season, with 521 million pounds or $65 \%$ produced in Pennsylvania (Norris, 2009). The major ingredients in mushroom-growing substrate from farms in Pennsylvania are typically recycled agricultural waste products and other materials, which include hay, straw and horse bedding, poultry litter, corn cobs, corn stover, cottonseed meal, cocoa hulls, and gypsum in various amounts and proportions (Chang and Miles, 1989; Stamets, 2000). The ingredients are mixed, blended, and irrigated thoroughly, placed inside a production facility, and pasteurized with steam heat to sterilize the substrate before inoculation with mushroom spawn (Wuest,

Financial support for this project was provided by the Mushroom Industry Farmer-Based Applied Research Program, administered through the American Mushroom Institute (Washington, DC), and by the Honorable Edward G. Rendell, Governor of the Commonwealth of Pennsylvania, administered through the Chester County Economic Development Council, Project No. C000029029 (Exton, PA).

${ }^{1}$ Pennsylvania State University, Berks Campus, Division of Science, 111 Luerssen Building, Reading, PA 19610

${ }^{2}$ Pennsylvania State University, Department of Plant Pathology, Buckhout Laboratory, University Park, PA 16802

${ }^{3}$ Corresponding author. E-mail: fidanza@psu.edu.
1982). Sphagnum peatmoss is added later in the growing process (Beyer, 2003; Chang and Hayes, 1978).

After a cropping cycle has been completed and the substrate has been depleted of nutrients needed for growing mushrooms, the substrate is removed from the production facility and the discarded material is then referred to as fresh mushroom compost (Beyer, 2003; Chang and Hayes, 1978; Wuest, 1982). Before removal, however, the substrate is again pasteurized with steam heat to eliminate the potential for unwanted fungi and weed seeds (Wuest, 1982). Fresh mushroom compost was previously called spent mushroom substrate or mislabeled as "mushroom soil" (American Mushroom Institute, unpublished data). Although weathered or outdoor-aged mushroom compost has been used as an organic fertilizer and soil amendment for plant production in agriculture and horticulture (Chong et al., 1991 b; Lohr et al., 1984a; Maher, 1991, 1994), limited information is available regarding the analysis of fresh mushroom compost (American Mushroom Institute, unpublished data). An estimated 650,000 to 700,000 yard $^{3}$ of fresh mushroom compost are generated annually by the mushroom industry in Pennsylvania (American Mushroom Institute, unpublished data; Fidanza and Davis, 2009). The objective of this project was to analyze the fresh mushroom compost produced in southeastern Pennsylvania for chemical and physical properties considered important for plant growth and soil improvement.

\section{Materials and methods}

During late Winter/early Spring 2005, 30 fresh mushroom compost samples were collected from mushroom farms in southeastern Pennsylvania, particularly the mushroom-growing regions in Berks and Chester counties. The samples were acquired as the material was being removed from a production facility, and were not allowed to stockpile or age outdoors. Each sample was placed in a l-gal plastic container and was securely shipped to the Agricultural Analytical Services Laboratory (Pennsylvania State University, University Park) for processing and analysis. Laboratory tests measured the following properties: $\mathrm{pH}$, carbon:nitrogen (C:N) ratio, soluble salts, solids, moisture, organic matter, carbon, total nitrogen $(\mathrm{N})$, organic nitrogen, ammonium nitrogen, phosphate $\left(\mathrm{P}_{2} \mathrm{O}_{5}\right)$, potash $\left(\mathrm{K}_{2} \mathrm{O}\right)$, calcium $(\mathrm{Ca})$, magnesium $(\mathrm{Mg})$, sulfur $(\mathrm{S})$, sodium $(\mathrm{Na})$, aluminum $(\mathrm{Al})$, iron $(\mathrm{Fe})$, manganese $(\mathrm{Mn})$, copper $(\mathrm{Cu})$, and zinc $(\mathrm{Zn})$. Although laboratory results reported $\mathrm{P}_{2} \mathrm{O}_{5}$ and $\mathrm{K}_{2} \mathrm{O}$ values, actual phosphorus $(\mathrm{P})$ and

\begin{tabular}{llll}
\hline $\begin{array}{l}\text { Units } \\
\begin{array}{l}\text { To convert U.S. to SI, } \\
\text { multiply by }\end{array}\end{array}$ & U.S. unit & SI unit & $\begin{array}{l}\text { To convert SI to U.S., } \\
\text { multiply by }\end{array}$ \\
\hline 0.4047 & acre(s) & $\mathrm{ha}$ & 2.4711 \\
3.7854 & gal & $\mathrm{L}$ & 0.2642 \\
2.54 & inch $(\mathrm{es})$ & $\mathrm{cm}$ & 0.3937 \\
0.4536 & $\mathrm{lb}$ & $\mathrm{kg}$ & 2.2046 \\
1.1209 & $\mathrm{lb} / \mathrm{acre}$ & $\mathrm{kg} \cdot \mathrm{ha}^{-1}$ & 0.8922 \\
0.5933 & lb/yard & $\mathrm{kg} \cdot \mathrm{m}^{-3}$ & 1.6856 \\
1 & mmho/cm & $\mathrm{dS} \cdot \mathrm{m}^{-1}$ & 1 \\
2.2417 & ton $/ \mathrm{acre}$ & $\mathrm{Mg} \cdot \mathrm{ha}^{-1}$ & 0.4461 \\
1.8893 & yard $/ \mathrm{acre}$ & $\mathrm{m}^{3} \cdot \mathrm{ha}^{-1}$ & 0.5293
\end{tabular}


potassium $(\mathrm{K})$ were calculated from $\mathrm{P}_{2} \mathrm{O}_{5}$ and $\mathrm{K}_{2} \mathrm{O}$, respectively (Brady and Weil, 1996). Two additional laboratory tests measured bulk density and particle size distribution. Laboratory test methods and procedures are based on the Test Methods for Evaluation of Compost and Composting program as recommended by the U.S. Composting Council (West Conshohocken, PA) and the American Society of Testing Materials (Rokonkoma, NY), and also based on analytical methods described in Eaton et al. (2005). A detailed list of the analytical methods used for each test can be obtained through Agricultural Analytical Services Laboratory. Of interest for growth media in horticulture, soluble salt content was measured indirectly from electrical conductivity (EC) using a 1:5 (compost:water) slurry (Agricultural Analytical Services Laboratory, unpublished data).

The laboratory tests determined compost characteristics on a wet weight, wet volume, and dry weight basis. Bulk density was determined "as is" (i.e., as received at the laboratory, and not oven-dried) on a wet volume basis [test method TMECC 3.01-A, U.S. Composting Council (Westerman, 1990)] and particle size also was determined "as is" on a wet weight basis. Data from all samples were compiled to determine mean, standard deviation, and the minimum and maximum values (Steel and Torrie, 1980) for each parameter (Statistix, version 9; Analytical Software, Tallahassee, FL). Also, wet volume laboratory results data were used to calculate the amount of plant nutrients in fresh mushroom compost per acre, as well as the sodium adsorption ratio (SAR) per acre (Swift, 2009). The SAR, calculated as follows,

$$
\mathrm{SAR}=\frac{\left[\mathrm{Na}^{+}\right]}{\sqrt{\frac{\left(\left[\mathrm{Ca}^{2+}\right]+\left[\mathrm{Mg}^{2+}\right]\right)}{2}}}
$$

compares $\mathrm{Na}$ concentration relative to the concentrations of $\mathrm{Ca}$ and $\mathrm{Mg}$ (Brady and Weil, 1996).

\section{Results and discussion}

PH AND C:N Ratio. Fresh mushroom compost had an average $\mathrm{pH}$ of 6.6 (Table 1) within the optimum soil $\mathrm{pH}$ range of 6.0 to 7.0 for growing most agricultural and horticultural crops (Acquaah, 2009; Foth, 1984). Lohr et al. (1984b) reported an average leachate $\mathrm{pH}$ of 8.0 for fresh mushroom compost. Only three

Table 1. Analysis of fresh mushroom compost on a wet weight basis.

\begin{tabular}{|c|c|c|c|c|}
\hline \multirow[b]{2}{*}{ Parameter measured $^{\mathrm{z}}$} & \multirow[b]{2}{*}{ Mean } & \multirow[b]{2}{*}{ SD } & \multicolumn{2}{|c|}{ Range } \\
\hline & & & Minimum & Maximum \\
\hline $\mathrm{pH}$ & 6.62 & 0.47 & 5.90 & 7.80 \\
\hline Carbon:nitrogen ratio & $12.79: 1$ & 1.00 & 10.50 & 14.90 \\
\hline Soluble salts $(\mathrm{mmho} / \mathrm{cm})^{y}$ & 13.30 & 1.80 & 9.68 & 17.97 \\
\hline Solids & 42.67 & 6.85 & 31.40 & 60.60 \\
\hline Moisture & 57.33 & 6.85 & 39.40 & 68.60 \\
\hline Organic matter & 25.86 & 3.69 & 20.40 & 37.50 \\
\hline Carbon & 14.29 & 2.15 & 10.60 & 18.80 \\
\hline Total nitrogen & 1.12 & 0.20 & 0.80 & 1.50 \\
\hline Organic nitrogen & 1.10 & 0.22 & 0.70 & 1.50 \\
\hline Ammonium nitrogen $\left(\mathrm{NH}_{4}-\mathrm{N}\right)$ & 0.03 & 0.01 & $<0.01$ & 0.06 \\
\hline Phosphorus & 0.29 & 0.08 & 0.15 & 0.52 \\
\hline Potassium & 1.04 & 0.24 & 0.61 & 1.55 \\
\hline Calcium & 2.32 & 0.60 & 1.29 & 3.59 \\
\hline Magnesium & 0.36 & 0.12 & 0.16 & 0.74 \\
\hline Sulfur & 0.86 & 0.19 & 0.55 & 1.22 \\
\hline Sodium & 0.11 & 0.04 & 0.05 & 0.20 \\
\hline Aluminum & 0.15 & 0.09 & 0.04 & 0.57 \\
\hline Iron & 0.18 & 0.10 & 0.04 & 0.43 \\
\hline Manganese & 0.02 & 0.01 & $<0.01$ & 0.05 \\
\hline Copper & $<0.01$ & $<0.01$ & $<0.01$ & 0.01 \\
\hline Zinc & $<0.01$ & $<0.01$ & $<0.01$ & 0.01 \\
\hline
\end{tabular}

${ }^{2}$ Fresh mushroom compost samples $(n=30)$ were collected in l-gal $(3.8 \mathrm{~L})$ containers and analyzed by the Agricultural Analytical Services Laboratory (Pennsylvania State University, University Park) from Jan. 2005 through Apr. 2005. Mushroom compost samples were analyzed "as is" when received at the laboratory for measurements on a wet weight basis. Actual phosphorus $(\mathrm{P})$ was calculated from laboratory-measured $\mathrm{P}_{2} \mathrm{O}_{5}(\mathrm{P}=$ $\left.\mathrm{P}_{2} \mathrm{O}_{5} \times 0.4365\right)$, and actual potassium $(\mathrm{K})$ was calculated from laboratory-measured $\mathrm{K}_{2} \mathrm{O}\left(\mathrm{K}=\mathrm{K}_{2} \mathrm{O} \times 0.8301\right)$. ${ }^{y}$ Soluble salts determined by measuring EC in a 1:5 (compost:water, weight ratio) slurry; $1 \mathrm{mmho} / \mathrm{cm}=1 \mathrm{dS} \cdot \mathrm{m}^{-1}$.

samples were used in that study from a single mushroom farm in Tennessee (Lohr et al., 1984b) compared with 30 samples from multiple farms in this investigation, and the amount and quality of materials used to make mushroom substrate is dramatically different in Pennsylvania (Beyer, 2003; Wuest, 1982; Wuest et al., 1995). The C:N ratio of fresh mushroom compost in this study averaged 13:1 (Table 1), within the desired range of 10:1 to 15:1 for ideal compost (Stoffella and Kahn, 2001).

Soluble salts. The average EC of fresh mushroom compost was 13.30 $\mathrm{mmho} / \mathrm{cm}$ (Table $\mathrm{l}$ ), which is not considered high enough to damage turfgrass (Landschoot and McNitt, 2005 ) or impede plant production (Wang et al., 1984). In addition, salt concentrations can be significantly diluted when a compost is incorporated or tilled into a soil or soil amendment (Stoffella and Kahn, 2001). Lohr et al. (1984b) reported an EC of $22 \mathrm{mmho} /$ $\mathrm{cm}$ for fresh mushroom compost, and concluded that $\mathrm{K}, \mathrm{Ca}$, and $\mathrm{Mg}$ concentrations accounted for $80 \%$ to $90 \%$ of total dissolved salts present in saturated paste extracts used to measure
EC in that study. However, it is difficult to compare soluble salt concentration in compost from previous research when different analytical methods are used (Carter, 1993). Although soluble salt concentration of compost is often a concern to practitioners (Tyler, 1996), this material has been used successfully in many plant production systems (Chong and Rinker, 1994; Chong et al., 1991a; Philippoussis et al., 2004; Romaine and Holcomb, 2001; Wang et al., 1984; Wuest et al., 1995).

BULK DENSITY, SOLIDS, AND MOISTURE. Mean bulk density (Table 2) averaged $574.73 \mathrm{lb} /$ yard $^{3}$ (wet volume), with over half of the weight attributed to water. Lohr et al. (1984b) reported an average bulk density of $428.12 \mathrm{lb} /$ yard $^{3}$ for fresh mushroom compost, and again, this lower value reflects a difference in the amount and quality of materials used to make mushroom substrate today in Pennsylvania (Beyer, 2003; Chang and Hayes, 1978; Wuest, 1982; Wuest and Fahy, 1992; Wuest et al., 1995). In this study, fresh mushroom compost contained an average amount of solids at $42.67 \%$ (wet weight) or 243.37 
$\mathrm{lb} / \operatorname{yard}^{3}$ (wet volume), and moisture at $57.33 \%$ (wet weight) or $331.47 \mathrm{lb} /$ $\operatorname{yard}^{3}$ (wet volume) (Tables 1 and 2 ). Fresh mushroom compost is within the ideal ranges for compost of 35\% to 55\% (wet weight) for solids and 45\% to 65\% (wet weight) for moisture (Stoffella and Kahn, 2001).

Organic MATter and CARbon. Organic matter content of fresh mushroom compost averaged $25.86 \%$ (wet weight), $146.73 \mathrm{lb} /$ yard $^{3}$ (wet volume) or $60.97 \%$ (dry weight), and an average carbon content of $14.29 \%$ (wet weight), $81.13 \mathrm{lb} /$ yard $^{3}$ (wet volume), or $33.42 \%$ (dry weight) (Tables $1-3$ ). The organic matter in mushroom compost consists of decomposed plant, animal, and fungal residues and materials, and is often recommended for use in land reclamation or soil remediation (Rupert, 1995), as well as plant production (Davis et al., 2006; Lemaire et al., 1985; Lohr et al., 1984a; Rinker, 2002; Wang et al., 1984; Wuest et al., 1995).

PRIMARY AND SECONDARY MACronUtrients. Average total N content of fresh mushroom compost was $1.12 \%$ (wet weight), $6.40 \mathrm{lb} /$ yard $^{3}$ (wet volume) or $2.65 \%$ (dry weight) (Tables 1-3). The majority of this $\mathrm{N}$ is in the organic form, with a very small amount in the ammonium form. In general, composts have low $\mathrm{N}$ content, typically in the $1 \%$ to $3 \%$ range (Acquaah, 2009). Average P content was $0.29 \%$ (wet weight), $1.67 \mathrm{lb} /$ yard $^{3}$ (wet volume) or $0.69 \%$ (dry weight) (Tables 1-3). Average K content was $1.04 \%$ (wet weight), $5.89 \mathrm{lb} /$ yard $^{3}$ (wet volume) or $2.44 \%$ (dry weight) (Tables 1-3). On average, fresh mushroom compost contains the secondary macronutrients $\mathrm{Ca}$ at $2.32 \%$ (wet weight), $13.17 \mathrm{lb} /$ yard $^{3}$ (wet volume) or $5.38 \%$ (dry weight), $\mathrm{Mg}$ at $0.36 \%$ (wet weight), $2.01 \mathrm{lb} / \operatorname{yard}^{3}$ (wet volume) or $0.83 \%$ (dry weight), and $S$ at $0.86 \%$ (wet weight), $4.91 \mathrm{lb} /$ yard $^{3}$ (wet volume) or $2.02 \%$ (dry weight) (Tables 1-3). Overall, the average amounts of primary and secondary macronutrients determined from the 30 samples tested did not show extreme minimum or maximum vales, thus indicating similar methods used by mushroom farms for producing this material in Pennsylvania (Beyer, 2003; Wuest, 1982).

Micronutrients. The micronutrients $\mathrm{Fe}, \mathrm{Mn}, \mathrm{Cu}, \mathrm{Zn}, \mathrm{Na}$, and $\mathrm{Al}$ were detected in fresh mushroom

Table 2. Analysis of fresh mushroom compost on a wet volume basis.

\begin{tabular}{|c|c|c|c|c|}
\hline \multirow[b]{3}{*}{ Parameter measured $^{\mathrm{z}}$} & \multirow[b]{2}{*}{ Mean } & \multirow[b]{2}{*}{ SD } & \multicolumn{2}{|c|}{ Range } \\
\hline & & & Minimum & Maximum \\
\hline & \multicolumn{4}{|c|}{$\left(1 \mathrm{~b} / \text { yard }^{3}\right)^{y}$} \\
\hline Bulk density & 574.73 & 82.05 & 432.00 & 777.00 \\
\hline Solids & 243.37 & 41.68 & 179.00 & 344.00 \\
\hline Moisture & 331.47 & 71.70 & 209.00 & 469.00 \\
\hline Organic matter & 146.73 & 17.67 & 119.00 & 199.00 \\
\hline Carbon & 81.13 & 10.52 & 61.00 & 105.00 \\
\hline Total nitrogen & 6.40 & 1.06 & 4.50 & 9.00 \\
\hline Organic nitrogen & 6.19 & 1.07 & 4.30 & 8.80 \\
\hline $\begin{array}{l}\text { Ammonium nitrogen } \\
\qquad\left(\mathrm{NH}_{4}-\mathrm{N}\right)\end{array}$ & 0.21 & 0.07 & 0.03 & 0.34 \\
\hline Phosphorus & 1.67 & 0.41 & 0.90 & 2.95 \\
\hline Potassium & 5.89 & 1.17 & 3.69 & 8.40 \\
\hline Calcium & 13.17 & 3.31 & 6.71 & 20.28 \\
\hline Magnesium & 2.01 & 0.61 & 0.99 & 3.53 \\
\hline Sulfur & 4.91 & 1.12 & 3.12 & 7.72 \\
\hline Sodium & 0.67 & 0.25 & 0.35 & 1.26 \\
\hline Aluminum & 0.89 & 0.53 & 0.28 & 3.07 \\
\hline Iron & 1.07 & 0.57 & 0.29 & 2.57 \\
\hline Manganese & 0.12 & 0.07 & 0.04 & 0.29 \\
\hline Copper & 0.03 & 0.01 & 0.02 & 0.08 \\
\hline Zinc & 0.05 & 0.02 & 0.03 & 0.09 \\
\hline
\end{tabular}

${ }^{2}$ Fresh mushroom compost samples $(n=30)$ were collected in l-gal $(3.8 \mathrm{~L})$ containers and analyzed by the Agricultural Analytical Services Laboratory (Pennsylvania State University, University Park) from Jan. 2005 through Apr. 2005. Mushroom compost samples were analyzed "as is" when received at the laboratory for measurements on a wet volume basis. Actual phosphorus $(\mathrm{P})$ was calculated from laboratory-measured $\mathrm{P}_{2} \mathrm{O}_{5}(\mathrm{P}=$ $\left.\mathrm{P}_{2} \mathrm{O}_{5} \times 0.4365\right)$, and actual potassium $(\mathrm{K})$ was calculated from laboratory-measured $\mathrm{K}_{2} \mathrm{O}\left(\mathrm{K}=\mathrm{K}_{2} \mathrm{O} \times 0.8301\right)$. ${ }^{2} 1 \mathrm{lb} / \mathrm{yard}^{3}=0.5933 \mathrm{~kg} \cdot \mathrm{m}^{-3}$.

Table 3. Analysis of fresh mushroom compost on a dry weight basis.

\begin{tabular}{|c|c|c|c|c|}
\hline \multirow[b]{3}{*}{ Parameter measured $^{\mathrm{z}}$} & \multirow[b]{2}{*}{ Mean } & \multirow[b]{2}{*}{ SD } & \multicolumn{2}{|c|}{ Range } \\
\hline & & & Minimum & $\overline{\text { Maximum }}$ \\
\hline & & & $(\%)$ & \\
\hline Organic matter & 60.97 & 5.42 & 50.90 & 72.70 \\
\hline Carbon & 33.42 & 4.27 & 23.80 & 43.90 \\
\hline Total nitrogen & 2.65 & 0.39 & 1.90 & 3.50 \\
\hline Organic nitrogen & 2.57 & 0.38 & 1.90 & 3.40 \\
\hline $\begin{array}{l}\text { Ammonium nitrogen } \\
\qquad\left(\mathrm{NH}_{4}-\mathrm{N}\right)\end{array}$ & 0.09 & 0.03 & 0.01 & 0.18 \\
\hline Phosphorus & 0.69 & 0.16 & 0.46 & 1.23 \\
\hline Potassium & 2.44 & 0.36 & 1.78 & 3.20 \\
\hline Calcium & 5.38 & 0.89 & 3.73 & 7.70 \\
\hline Magnesium & 0.83 & 0.23 & 0.50 & 1.84 \\
\hline Sulfur & 2.02 & 0.36 & 1.49 & 2.70 \\
\hline Sodium & 0.28 & 0.09 & 0.14 & 0.45 \\
\hline Aluminum & 0.36 & 0.17 & 0.13 & 0.95 \\
\hline Iron & 0.43 & 0.18 & 0.15 & 0.85 \\
\hline Manganese & 0.05 & 0.01 & 0.02 & 0.10 \\
\hline Copper & 0.02 & $<0.01$ & 0.01 & 0.03 \\
\hline Zinc & 0.02 & 0.01 & 0.01 & 0.04 \\
\hline
\end{tabular}

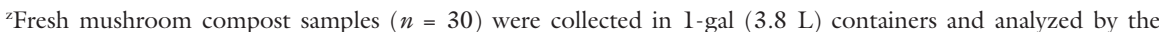
Agricultural Analytical Services Laboratory (Pennsylvania State University, University Park) from Jan. 2005 through Apr. 2005. Mushroom compost samples were first oven-dried to remove moisture and then analyzed on a dry weight basis. Actual phosphorus $(\mathrm{P})$ was calculated from laboratory-measured $\mathrm{P}_{2} \mathrm{O}_{5}\left(\mathrm{P}=\mathrm{P}_{2} \mathrm{O}_{5} \times 0.4365\right)$, and actual potassium $(\mathrm{K})$ was calculated from laboratory-measured $\mathrm{K}_{2} \mathrm{O}\left(\mathrm{K}=\mathrm{K}_{2} \mathrm{O} \times 0.8301\right)$.

compost at a very low average range of $<0.01 \%$ to $0.18 \%$ (wet weight), 0.03 to $1.07 \mathrm{lb} /$ yard $^{3}$ (wet volume), or $0.02 \%$ to $0.43 \%$ (dry weight) (Tables
1-3). This information is consistent with previous findings on the micronutrient content of aged mushroom compost (Wuest and Fahy, 1992). 
Amount of $\mathbf{N}$ And $\mathbf{P}$ per acre. The amount of plant nutrients supplied on a per acre basis is useful in field or horticultural crop production to determine nutrients provided by compost and those needed from additional fertilizer inputs (Brady and Weil, 1996). To uniformly apply l-inch-thick fresh mushroom compost to 1 acre of land would require $\approx 40$ tons/acre or 139 yard ${ }^{3} /$ acre of fresh mushroom compost as calculated from an average

Table 4. Amount of plant nutrients from fresh mushroom compost applied to 1 acre (0.4 ha).

\begin{tabular}{|c|c|}
\hline $\begin{array}{l}\text { Parameter } \\
\text { measured }\end{array}$ & $\begin{array}{c}\text { Amount } \\
(\text { lb } / \text { acre })^{\mathrm{z}}\end{array}$ \\
\hline Solids & 33,877 \\
\hline Moisture & 46,140 \\
\hline Organic matter & 20,425 \\
\hline Carbon & 11,294 \\
\hline Total nitrogen & 891 \\
\hline Organic nitrogen & 862 \\
\hline $\begin{array}{l}\text { Ammonium nitrogen } \\
\left(\mathrm{NH}_{4}-\mathrm{N}\right)\end{array}$ & 29 \\
\hline Phosphorus & 232 \\
\hline Potassium & 820 \\
\hline Calcium & 1,834 \\
\hline Magnesium & 280 \\
\hline Sulfur & 683 \\
\hline Sodium & 94 \\
\hline Aluminum & 124 \\
\hline Iron & 150 \\
\hline Manganese & 17 \\
\hline Copper & 6 \\
\hline Zinc & 7 \\
\hline \multicolumn{2}{|c|}{$\begin{array}{l}{ }^{2} \text { Calculation based on applying a } \mathrm{l} \text {-inch }(2.5 \mathrm{~cm}) \\
\text { thickness of fresh mushroom compost on a wet volume } \\
\text { basis to } \mathrm{l} \text { acre of land, which requires } \approx 139 \mathrm{yard}^{3} / \text { acre } \\
\left(262.6 \mathrm{~m}^{3} \cdot \mathrm{ha}^{-1}\right) \text { or } 40 \text { tons } / \text { acre }\left(89.7 \mathrm{Mg} \cdot \mathrm{Ma}^{-1}\right) \text { fresh } \\
\text { mushroom compost calculated from an average bulk } \\
\text { density of } 575 \mathrm{lb} / \mathrm{yard}^{3}\left(341.1 \mathrm{~kg} \cdot \mathrm{m}^{-3}\right) \text { and informa- } \\
\text { tion from Table } 2 \text {. Actual phosphorus }(\mathrm{P}) \text { was calcu- } \\
\text { lated from laboratory-measured } \mathrm{P}_{2} \mathrm{O}_{5}\left(\mathrm{P}=\mathrm{P}_{2} \mathrm{O}_{5} \times\right. \\
0.4365) \text {, and actual potassium }(\mathrm{K}) \text { was calculated from } \\
\text { laboratory-measured } \mathrm{K}_{2} \mathrm{O}\left(\mathrm{K}=\mathrm{K}_{2} \mathrm{O} \times 0.8301\right) ; \mathrm{ll} / \mathrm{lb} / \\
\text { acre }=1.1209 \mathrm{~kg} \cdot \mathrm{ha}^{-1} \text {. }\end{array}$} \\
\hline
\end{tabular}

bulk density of $575 \mathrm{lb} /$ yard $^{3}$ (Table 4). A 1-inch-thick layer of mushroom compost is typically applied to agricultural fields in Pennsylvania (Wuest et al., 1995). Forty tons of material would supply $891 \mathrm{lb}$ total $\mathrm{N}$, of which $29 \mathrm{lb}$ is in the form of ammonium N and $862 \mathrm{lb}$ is in the form of organic $\mathrm{N}$ (Table 4). With the recent increase in synthetic fertilizer costs (Torres, 2008), N supplied from fresh mushroom compost could help meet plant nutrient needs while reducing expenses by needing less fertilizer inputs (Stewart et al., 1998). Also, 40 tons/acre of fresh mushroom compost results in $232 \mathrm{lb}$ of $\mathrm{P}$ being applied (Table 4). Information on $\mathrm{P}$ on a per-acre basis is useful for developing and maintaining soil nutrient management plans and practices (Jones, 2003).

SODIUM ADSORPTION RATIO. Although SAR is typically based on concentration of ions in solution (Carter, 1993), a calculated (Swift, 2009) estimate from 40 tons fresh mushroom compost applied to 1 acre results in $\mathrm{SAR}=0.38$. A SAR $\geq 15$ would typically indicate excess $\mathrm{Na}$ accumulation compared with $\mathrm{Ca}$ and $\mathrm{Mg}$, and that sodium would be adsorbed by soil clay particles, thus causing problems with soil aggregation and drainage, as well as inhibiting water absorption by plant roots (Brady and Weil, 1996).

Particle size. On average, 91\% of fresh mushroom compost particles measured $\leq 3 / 8$ inch in diameter, with $\approx 8 \%$ at $3 / 8$ to $5 / 8$ inch, and $<1 \%$ at $5 / 8$ to 1 inch (Table 5 ). No particles were measured $>1$ inch in diameter. Overall, this material is of a consistent and uniform size and is easy to handle, apply, and distribute to lawns, landscapes, sports fields, and agricultural fields, and is amendable for most horti-

Table 5. Particle size distribution of fresh mushroom compost on a wet weight basis.

\begin{tabular}{|c|c|c|c|c|}
\hline \multirow[b]{3}{*}{ Particle diam (inches) ${ }^{\mathrm{z}}$} & \multirow[b]{2}{*}{ Mean } & \multirow[b]{2}{*}{ SD } & \multicolumn{2}{|c|}{ Range } \\
\hline & & & Minimum & Maximum \\
\hline & & & $(\%)$ & \\
\hline$\geq 2$ inch & 0.00 & 0.00 & 0.00 & 0.00 \\
\hline $1-2$ inch & 0.00 & 0.00 & 0.00 & 0.00 \\
\hline $5 / 8-1$ inch & 0.52 & 1.48 & 0.00 & 6.38 \\
\hline $3 / 8-5 / 8$ inch & 7.89 & 6.75 & 0.36 & 26.39 \\
\hline $1 / 8-3 / 8$ inch & 28.84 & 8.31 & 4.30 & 45.15 \\
\hline$<1 / 8$ inch & 62.05 & 11.00 & 39.79 & 77.15 \\
\hline
\end{tabular}

${ }^{2}$ Fresh mushroom compost samples $(n=30)$ were collected in 1 -gal $(3.8 \mathrm{~L})$ containers and analyzed by the Agricultural Analytical Services Laboratory (Pennsylvania State University, University Park) from Jan. 2005 through Apr. 2005. Mushroom compost samples were analyzed "as is" when received at the laboratory for particle size measurements on a wet weight basis; 1 inch $=2.54 \mathrm{~cm}$. cultural uses (Landschoot and McNitt, 1994; Stoffella and Kahn, 2001).

In Pennsylvania, the state legislature has recently reclassified fresh mushroom compost from an agricultural waste product to now listing it as a fertilizer and soil amendment (American Mushroom Institute, unpublished data). While stockpiled outdoor or passively aged mushroom compost has been used for many agricultural and horticultural purposes, the accumulation of weed seeds deposited into that material by nature has provided challenges to the end user, as well as the cost and maintenance of storing that material by the mushroom industry (Rinker, 2002). In conclusion, fresh mushroom compost should be considered a viable, recycled agricultural product useful as a soil amendment or natural organic fertilizer, and could potentially be surface-applied or incorporated into soil or plant growth media. The methods used to grow white button mushrooms are very similar among the farms in southeastern Pennsylvania (Beyer, 2003; Wuest, 1982). Therefore, results of the analysis of fresh mushroom compost in this report should be representative of the chemical and physical properties throughout that material as produced in Pennsylvania.

\section{Literature cited}

Acquaah, G. 2009. Horticulture, principles and practices. Prentice Hall, Upper Saddle River, NJ.

Beyer, D.M. 2003. Basic procedures for Agaricus mushroom growing. Pennsylvania State Univ., Coop. Ext., University Park.

Brady, N.C. and R.R. Weil. 1996. The nature and properties of soils. Prentice Hall, Upper Saddle River, NJ.

Carter, M.R. 1993. Soil sampling and methods of analysis. CRC Press, Boca Raton, FL.

Chang, S.T. and P.G. Miles. 1989. Edible mushrooms and their cultivation. CRC Press, Boca Raton, FL.

Chang, S.T. and W.A. Hayes. 1978. The biology and cultivation of edible mushrooms. Academic Press, New York.

Chong, C. and D.L. Rinker. 1994. Use of spent mushroom substrate for growing containerized woody ornamentals: An overview. Compost Sci. Util. 2:45-53.

Chong, C., D.L. Rinker, and R.A. Cline. 1991b. A comparison of five spent mushroom composts for container culture of 
ornamental shrubs. Mushroom Sci. 13: $637-644$

Chong, C., R.A. Cline, and D.L. Rinker. 1991a. Growth and mineral nutrition status of containerized woody species in media amended with spent mushroom compost. J. Amer. Soc. Hort. Sci. 116: $242-247$

Davis, D.D., L.J. Kuhns, and T.L. Harpster. 2006. Use of mushroom compost to suppress artillery fungi. J. Environ. Hort. 24:212-215.

Eaton, A.D., L.S. Clesceri, E.W. Rice, A.E. Greenberg, and M.H. Franson. 2005. Standard methods for the examination of water and wastewater. 21 st ed. United Book Press, Baltimore.

Fidanza, M.A. and D.D. Davis. 2009. Recycled mushroom compost suppresses bird's nest fungi in landscape mulch. J. Environ. Hort. 27:238-240.

Foth, H.D. 1984. Fundamentals of soil science. Wiley, New York.

Jones, J.B. 2003. Agronomic handbook: Management of crops, soils, and their fertility. CRC Press, Boca Raton, FL.

Landschoot, P.J. and A.S. McNitt. 1994. Improving turf with compost. Biocycle 35:54-57.

Landschoot, P.J. and A.S. McNitt. 2005. Using spent mushroom substrate (mushroom soil) as a soil amendment to improve turf. Pennsylvania State Univ., Coop. Ext., University Park.

Lemaire, F., A. Dartigues, and L.M. Riviere. 1985. Properties of substrate made with spent mushroom compost. Acta Hort. 172:13-29.

Lohr, V.I., R.G. O'Brien, and D.L. Coffey. 1984a. Spent mushroom compost in soilless media and its effect on the yield and quality of transplants. J. Amer. Soc. Hort. Sci. 109:693-697.

Lohr, V.I., S.H. Wang, and J.D. Wolt. 1984b. Physical and chemical characteristics of fresh and aged spent mushroom compost. HortScience 19:681-683.

Maher, M.J. 1991. Spent mushroom compost (SMS) as a nutrient source in peat based potting substrate. Mushroom Sci. 13:645-652.

Maher, M.J. 1994. The use of spent mushroom substrate as an organic manure and plant substrate component. Compost Sci. Util. 2:37-44.

Norris, D. 2009. Mushrooms. Natl. Agr. Stat. Serv., Agr. Stat. Board, U.S. Dept. Agr., Washington, DC.

Philippoussis, A., G.I. Zervakis, P. Diamantpoulou, K. Papadopoulou, and C. Ehaliotis. 2004. Use of spent mush room compost as a substrate for plant growth and against plant infections caused by Phytophthora. Mushroom Sci. 16:579584.

Rinker, D.L. 2002. Handling and using "spent" mushroom substrates around the world, p. 43-60. In: J.E. Sanchez, D.J. Royse, and G. Hernandez (eds.). Proc. 4th Intl. Conf. Mushroom Biol. Mushroom Products, 20-23 Feb. 2002, Cuernavaca, México.

Romaine, C.P. and E.J. Holcomb. 2001. Spent mushroom substrate: A novel multifunctional constituent of potting medium for plants. Mushroom News 49:4-15.

Rupert, D.R. 1995. Use of spent mushroom substrate in stabilizing disturbed and commercial sites. Compost Sci. Util. $3: 80-83$.

Stamets, P. 2000. Growing gourmet and medicinal mushrooms. Ten Speed Press, Berkeley, CA.
Steel, R.G.D. and J.H. Torrie. 1980. Principles and procedures of statistics: A biometrial approach. McGraw Hill, New York.

Stewart, D.P.C., K.C. Cameron, and I.S. Cornforth. 1998. Effects of spent mushroom substrate on soil chemical conditions and plant growth in an intensive horticultural system: A comparison with inorganic fertiliser. Aust. J. Soil Res. 36:185-198.

Stoffella, P.J. and B.A. Kahn. 2001. Compost utilization in horticultural cropping systems. Lewis Publishers, Boca Raton, FL.

Swift, C.E. 2009. Sodium adsorption ratio (SAR). 12 Nov. 2009. <http://www. colostate.edu/Dept/CoopExt/TRA/ PLANTS/sar>.

Torres, C. 2008. No relief in sight for high fertilizer prices. 9 May 2008. <http://www. lancasterfarming.com/node/1246>.

Tyler, R.W. 1996. Winning the organics game. ASHS Press, Alexandria, VA.

Wang, S.H.L., V.I. Lohr, and D.L. Coffey. 1984. Spent mushroom compost as a soil amendment for vegetables. J. Amer. Soc. Hort. Sci. 109:698-702.

Westerman, R.L. 1990. Soil testing and plant analysis. Soil Sci. Soc. Amer., Madison, WI.

Wuest, P.J. 1982. Penn State handbook for commercial mushroom growers. Pennsylvania State University Press, University Park, PA.

Wuest, P.J. and H.K. Fahy. 1992. Spent mushroom compost: Its origins and components and impact on water quality. Mushroom News 40:27-33.

Wuest, P.J., H.K. Fahy, and J. Fahy. 1995. Use of spent mushroom substrate (SMS) for corn (maize) production and its effect on surface water quality. Compost Sci. Util. 3:46-50. 